\title{
Susceptibility of developmental stages of the spider, Tegenaria atrica C.L. Koch to selected insecticides from different chemical groups
}

\author{
Wrażliwość stadiów rozwojowych pająka kątnika większego, \\ Tegenaria atrica C.L. Koch na wybrane insektycydy \\ z różnych grup chemicznych
}

\author{
Maryla Szczepanik, Julita Templin, Teresa Napiórkowska
}

\begin{abstract}
Summary
The susceptibility of larvae and nymphs $s_{1}$ of the spider Tegenaria atrica C.L. Koch to four insecticides (Vertimec 018 EC, SpinTor 240 SC, Actara 25 WG oraz Fastac 100 EC) containing the active substances from different chemical groups was studied under laboratory conditions. Insecticides were applied by contact (insecticide-treated filter paper) or spray method. Vertimec $018 \mathrm{EC}$ and Actara 25 WG were used at $0.05,0.1$ and $0.2 \%$ concentration, SpinTor 240 SC at $0.02,0.04$ and $0.08 \%$ solutions and Fastac 100 EC dose was $0.005,0.01$ and $0.02 \%$. Results show that spiders vary in responses to insecticides. The most toxic for both developmental stages was Fastac 100 EC (mortality of larvae was $94.22-97.22 \%$, nymphs ${ }_{1}$ 85.72-97.14\%). Tiametoxam and abamectin showed low toxicity and their doses suggested for commercial application are safe for the early stages of $T$. atrica. Low dose of spinosad was relatively safe (7.5-22.5\% mortality), but higher concentrations posed a risk to this group of predators.
\end{abstract}

Key words: abamectin, tiametoxam, spinosad, alpha-cypermethrin, Tegenaria atrica

\section{Streszczenie}

Zbadano w warunkach laboratoryjnych wrażliwość larw i nimf ${ }_{1}$ pająka kątnika, Tegenaria atrica C.L. Koch na cztery insektycydy (Vertimec 018 EC, SpinTor 240 SC, Actara 25 WG oraz Fastac 100 EC) zawierające substancje czynne z różnych grup chemicznych. Stosowano metodę kolonizacji na traktowanym podłożu (bibuła filtracyjna) oraz metodę bezpośredniego opryskiwania larw lub nimf 1 umieszczonych w szalkach Petriego. Preparaty Vertimec 018 EC oraz Actara 25 WG stosowano w stężeniu 0,05; 0,1 i 0,2\%, SpinTor 240 SC w dawkach 0,02; 0,04 i 0,08\%, Fastac 100 EC zastosowano w 0,005; 0,01 i 0,02\% stężeniu. Otrzymane wyniki wskazują na zróżnicowaną wrażliwość pająków. Najbardziej toksycznym insektycydem dla młodocianych stadiów rozwojowych $T$. atrica był Fastac 100 EC (śmiertelność larw 94,22-97,22\%, nimf 1 85,72-97,14\%). Środki owadobójcze zawierające tiametoksam i abamektynę wykazywały niską toksyczność, zalecane dawki polowe tych insektycydów są bezpieczne dla wczesnych stadiów rozwojowych $T$. atrica. Niskie dawki spinosadu powodowały śmiertelność na poziomie 7,5-22,5\%, jednak wyższe stężenia preparatu SpinTor 240 SC stanowią zagrożenie dla tej grupy drapieżców. Powodują nie tylko wzrost śmiertelności nimf ${ }_{1}$, ale również zahamowanie procesu linienia.

Słowa kluczowe: abamektyna, tiametoksam, spinosad, alfa-cypermetryna, Tegenaria atrica

Uniwersytet Mikołaja Kopernika

Wydział Biologii i Ochrony Środowiska

Lwowska 1, 87-100 Toruń

mszczep@umk.pl 


\section{Wstęp / Introduction}

Szeroko stosowane w ostatnich dekadach środki owadobójcze są jednym $\mathrm{z}$ istotnych czynników stresogennych dla pająków. Stawonogi te, ze względu na duży potencjał jako drapieżcy, odgrywają ważną rolę w redukcji populacji wielu gatunków szkodników roślin. Jednak poprzez liczne zasiedlanie ekosystemów rolniczych i leśnych narażone są na negatywne skutki działania insektycydów. Ich wrażliwość na powszechnie stosowane środki chemiczne do ochrony upraw rolniczych, sadowniczych i leśnych o różnych mechanizmach działania wymaga szczególnej uwagi. Mechanizmy i poziomy tolerancji insektycydów w przypadku tej grupy drapieżców są stosunkowo słabo poznane (Wilczek 2008). Większość badań została przeprowadzona na dorosłych osobnikach różnych gatunków pająków (Pekár 1998; Řezáč i wsp. 2010). Tymczasem przeżywalność ich wczesnych stadiów rozwojowych w środowiskach, gdzie stosowane są insektycydy jest równie ważnym czynnikiem decydującym o liczebności populacji tych pożytecznych organizmów.

Celem prowadzonych badań była ocena wrażliwości larw i nimf 1 pająka kątnika, Tegenaria atrica C.L. Koch na cztery środki owadobójcze. Gatunek ten jest powszechnie spotykany nie tylko w Polsce, ale i w całej Europie. Wykazuje stosunkowo małą wybiórczość pokarmową i żywi się prawie wszystkimi stawonogami. Pokarmem wczesnych stadiów rozwojowych tego gatunku mogą być także jaja wielu gatunków owadów (Prószyński i Staręga 1971; Nyffeler i wsp. 1990; Jacuński i wsp. 1999).

\section{Materiały i metody / Materials and methods}

W badaniach laboratoryjnych zastosowano cztery środki owadobójcze zawierające substancje czynne z różnych grup chemicznych, tj. abamektynę (Vertimec 018 EC), spinosad (SpinTor $240 \mathrm{SC}$ ), tiametoksam (Actara $25 \mathrm{WG}$ ) oraz alfa-cypermetrynę (Fastac 100 EC). Abamektyna i spinosad są substancjami pochodzenia naturalnego z grupy makrocyklicznych laktonów, dwa pozostałe związki to substancje syntetyczne $\mathrm{z}$ grupy neonikotynoidów (tiametoksam) i pyretroidów (alfa-cypermetryna). W doświadczeniach prowadzonych $\mathrm{w}$ temperaturze pokojowej $\left(18-20^{\circ} \mathrm{C}\right)$ stosowano dwie wersje metody kontaktowej. W pierwszej (oznaczonej jako metoda I), kolonizowano larwy lub nimfy $_{1}$ w szalkach Petriego o średnicy 9,0 cm (pole powierzchni $=63,58 \mathrm{~cm}^{2}$ ) wyłożonych bibułą filtracyjna, na którą wcześniej nanoszono $1 \mathrm{ml}$ wodnego roztworu insektycydu; w drugiej (metoda II) aplikowano te same dawki insektycydów przez opryskiwanie znajdujących się w szalce wyłożonej bibułą filtracyjną larw lub nimf T. atrica. Dawką wyjściową była dawka zalecana przez producenta danego insektycydu. Kolejne dawki wprowadzano w zależności od wrażliwości pająków. Preparaty Vertimec 018 EC oraz Actara $25 \mathrm{WG}$ stosowano w stężeniu 0,$05 ; 0,1$ i $0,2 \%$, SpinTor240 SC w dawkach 0,02 ; 0,04 i $0,08 \%$. Preparat Fastac 100 EC, ze względu na wysoką wrażliwość badanych stadiów rozwojowych T. atrica zastosowano w najniższych dawkach $(0,005$; $0,01$ i $0,02 \%)$. W próbach kontrolnych do opryskiwania stosowano te same objętości wody destylowanej. Obserwacje nad przeżywalnością traktowanych stadiów prowadzono do momentu linienia w kolejne stadium rozwojowe. Śmiertelność obserwowaną korygowano stosując regułę Abbotta (1925). Wszystkie doświadczenia powtarzano 4-krotnie. Wrażliwość larw i nimf 1 porównywano za pomocą testu Studenta $(\mathrm{p}<0,05)$.

\section{Wyniki i dyskusja / Results and discussion}

Wyniki przeprowadzonych badań przedstawione na rysunkach 1-4 wskazują na zróżnicowany poziom wrażliwości larw i nimf 1 . atrica na insektycydy. Po zastosowaniu zalecanej $\mathrm{w}$ etykiecie dawki $(0,05 \%)$ preparatu Vertimec 018 EC śmiertelność larw T. atrica nie przekraczała $30 \%$, a śmiertelność nimf 1 była na poziomie 11,43-15,71\%. Przy zwiększonej dawce tego insektycydu obserwowano wzrost śmiertelności, szczególnie nimf . $_{1}$. Otrzymane wyniki wskazuja, że czterokrotne przekroczenie zalecanej dawki polowej może być dużym zagrożeniem dla tego stadium - niezależnie od zastosowanej metody aplikacji zginęło 82,86-97,14\% nimf (rys. 1a, b). Według ogólnie przyjętej skali toksyczności insektycydów wobec organizmów pożytecznych, Vertimec 018 EC stosowany zgodnie $\mathrm{z}$ zaleceniami umieszczonymi w etykiecie jest preparatem nietoksycznym dla nimf ${ }_{1}$ i nisko toksycznym dla larw T. atrica.

Tiametoksam, związek z grupy neonikotynoidów, które są agonistami nikotynowych i nikotynowo-muskarynowych receptorów acetylocholiny, był znacznie lepiej tolerowany zarówno przez larwy, jak i nimfy. ${ }_{1}$. Zgodnie $\mathrm{z}$ etykietą najczęściej stosowane $\mathrm{w}$ praktyce dawki zawierają się $\mathrm{w}$ przedziale $0,02-0,05 \%$ i są uzależnione od rodzaju chronionej uprawy oraz gatunku i liczebności szkodnika. Śmiertelność larw T. atrica przy $0,05 \%$ dawce, jak i 2-krotnie wyższej nie przekroczyła poziomu $25 \%$, przeżywalność nimf była jeszcze wyższa i wynosiła 87,14$92,1 \%$. Nie obserwowano też istotnych różnic związanych z zastosowaną metodą aplikacji. Wyraźny wzrost śmiertelności nastąił jedynie po potraktowaniu nimf roztworem insektycydu o stężeniu $0,2 \%$ (rys. $2 \mathrm{a}, \mathrm{b}$ ). Tak więc, tiametoksam można zaliczyć do bezpiecznych i nietoksycznych wobec wczesnych stadiów rozwojowych T. atrica insektycydów.

SpinTor 240 SC, którego substancja czynna - spinosad blokuje kanały chlorkowe komórek nerwowych związane $\mathrm{z}$ receptorami kwasu gamaaminomasłowego GABA, w praktyce stosowany jest $\mathrm{w}$ stężeniach $0,04-0,1 \%$. Wyższe stężenia zalecane są głównie do ochrony roślin sadowniczych przy dużej liczebności szkodników. Niskie dawki spinosadu wykazywały stosunkowo małą

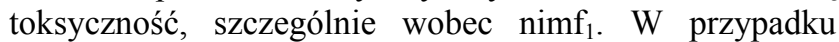
kontaktu $\mathrm{z}$ traktowanym podłożem (metoda I) wszystkie nimfy $_{1}$ przeżyły, po zastosowaniu metody II nie przeżyło tylko kilka osobników (śmiertelność 7,5\%). Wzrost dawki preparatu może stanowić jednak zagrożenie dla tej grupy drapieżców. Wyższe stężenia preparatu powodowały nie tylko wzrost śmiertelności nimf ${ }_{1}$, ale również zahamowanie procesu linienia. Zjawisko to obserwowano po kolonizacji nimf ${ }_{1}$ na podłożu traktowanym $0,08 \%$ dawką 
spinosadu. W tym przypadku zanotowano tylko $27,14 \%$ martwych osobników, ale aż 56,6\% tych ,przeżywających" nie przeszło w stadium nimfy ${ }_{2} \mathrm{i}$ w rezultacie zginęło. Można więc uznać, że w wyniku zastosowania metody I przy dawce $0,08 \%$ śmiertelność nimf ${ }_{1}$ wynosiła $67,14 \%$ (rys. 3a). Szczególnie wysoką śmiertelność obserwowano wśród nimf ${ }_{1}$, które zostały potraktowane insektycydem (metoda II). Wynosiła ona aż $80 \%$ po zastosowaniu zarówno 0,04, jak i $0,08 \%$ stężenia (rys. 3b). Przy tej metodzie aplikacji obserwowano także zahamowanie procesu linienia wśród nimf ${ }_{1}$. Podobnych zaburzeń nie odnotowano wśród larw. Wszystkie osobniki, które przeżyły eksperymenty przeszły w stadium nimfy ${ }_{1}$.
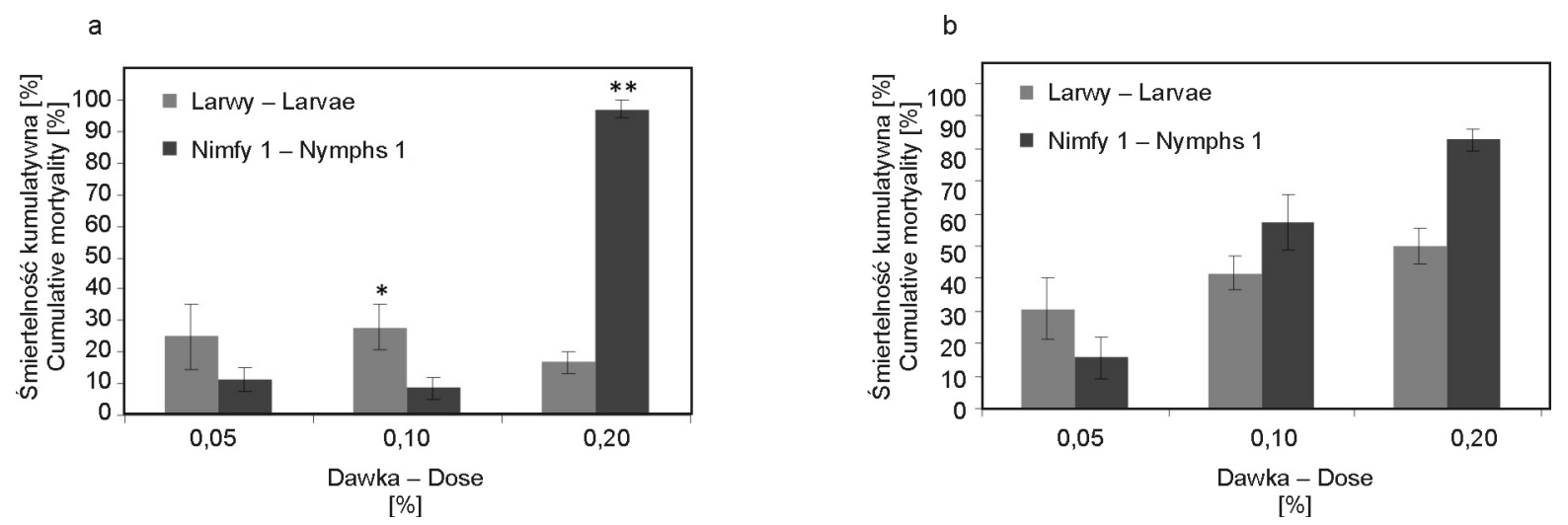

Rys. 1. Wrażliwość larw i nimf 1 T. atrica na abamektynę. a - metoda I; b - metoda II. Różnice istotne statystycznie: *p $<0,05$; $* * \mathrm{p}<0,001$ (test t-Studenta)

Fig. 1. Susceptibility of larvae and nymphs 1 T. atrica to abamectin. a - method I; b - method II. Differences statistically significant at $* \mathrm{p}<0.05 ; * * \mathrm{p}<0.001$ (Student t-test)
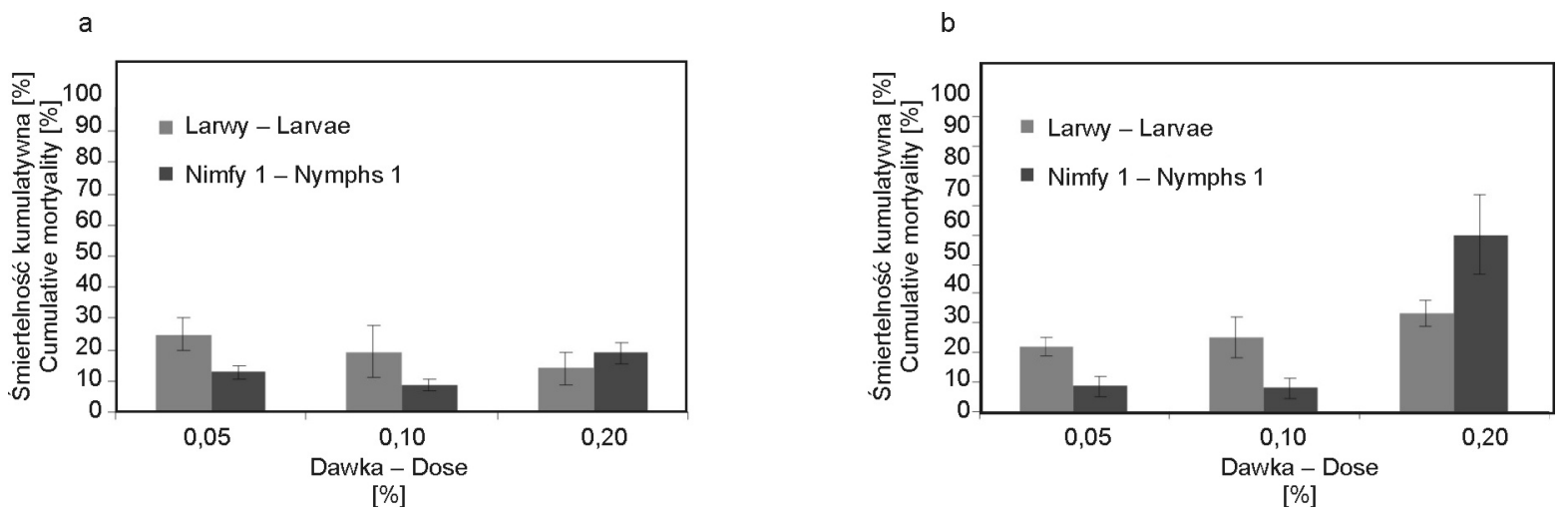

Rys. 2. Wrażliwość larw i nimf ${ }_{1} T$. atrica na tiametoksam. a - metoda I; b - metoda II

Fig. 2. Susceptibility of larvae and nymphs ${ }_{1} T$. atrica to tiametoxam. a-method I; b-method II

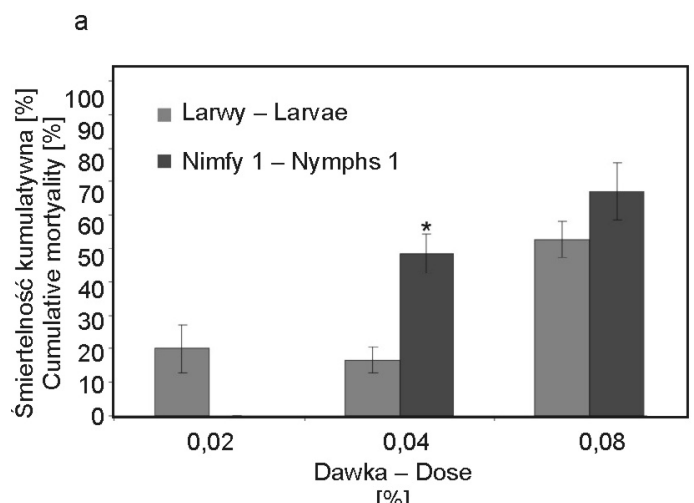

[\%]

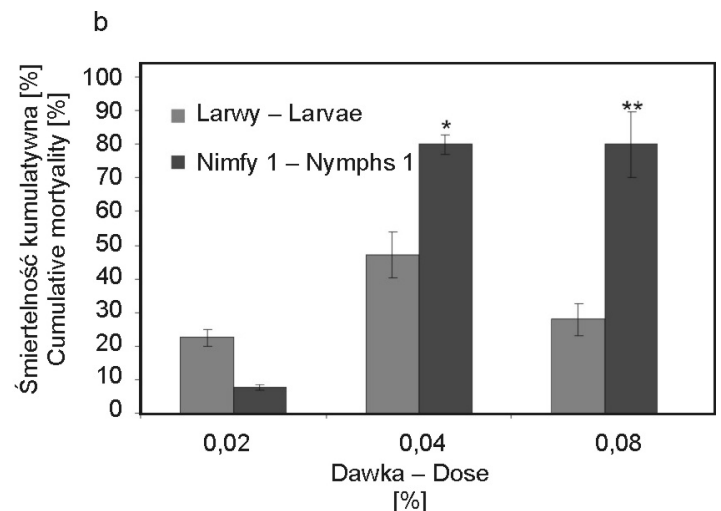

[\%]

Rys. 3. Wrażliwość larw i nimf 1 T. atrica na spinosad. a - metoda I; b - metoda II. Różnice istotne statystycznie: *p $<0,05 ; * * \mathrm{p}<0,01$ (test t-Studenta)

Fig. 3. Susceptibility of larvae and nymphs 1 T. atrica to spinosad. a - method I; b - method II. Differences statistically significant at ${ }^{*} \mathrm{p}<0.05 ; * * \mathrm{p}<0.01$ (Student t-test) 


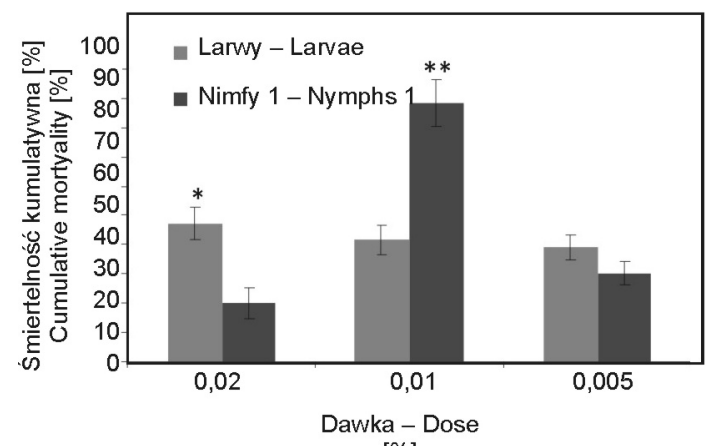

b

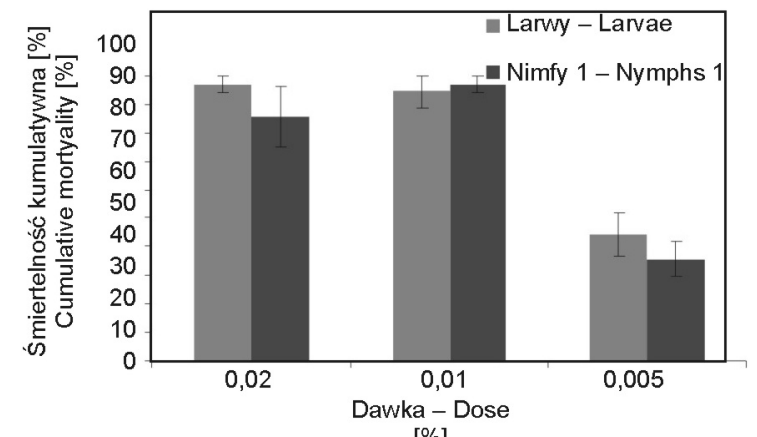

$[\%]$

Rys. 4. Wrażliwość larw i nimf 1 T. atrica na alfa-cypermetrynę. a - metoda I; b - metoda II. Różnice istotne statystycznie: *p $<0,05$; $* * \mathrm{p}<0,01$ (test t-Studenta)

Fig. 4. Susceptibility of larvae and nymphs ${ }_{1}$ T. atrica to alfa-cypermethrin. a - method I; b - method II. Differences statistically significant at $* \mathrm{p}<0.05 ; * \mathrm{*}<0.01$ (Student t-test)

Fastac 100 EC, z grupy syntetycznych pyretroidów, których mechanizm toksycznego działania polega na modulowaniu kinetyki otwierania i zamykania bramkowanych napięciem kanałów sodowych błon komórek nerwowych, stanowi największe zagrożenie dla pająków. W zabiegach ochrony roślin stosowany jest najczęściej w postaci $0,015-0,03 \%$ roztworów. Użyte w badaniach laboratoryjnych dawki mieszczące się w zakresie dawek polowych $(0,01$ i $0,02 \%)$ były bardzo toksyczne, szczególnie po zastosowaniu metody II. Śmiertelność larw była na poziomie $94,22-97,22 \%$, a $\operatorname{nimf}_{1}$ na poziomie 85,72-97,14\% (rys. 4a, b).

Analiza otrzymanych wyników wskazuje, że najmniejsze zagrożenie dla wczesnych stadiów rozwojowych T. atrica stwarza tiametoksam oraz abamektyna. Wyniki te korespondują z obserwacjami Amalin i wsp. (2000). Badania laboratoryjne przeprowadzone na młodocianych stadiach pająka Hibana velox (Becker) wykazały umiarkowaną toksyczność abamektyny i imidaklopridu. Niską toksyczność związków z grupy neonikotynoidów wobec pająków potwierdzają także badania Topy i wsp. (2009) prowadzone $\mathrm{w}$ sadach, gdzie stosowano między innymi Mospilan 20 SP (substancja czynna - acetamipryd). Podobnie, badania laboratoryjne prowadzone przez Řezáč i wsp. (2010) wskazują na brak negatywnego oddziaływania acetamiprydu na pająa Philodromus cespitum (Walckenaer). Badania prowadzone przez ten zespół potwierdzają także niekorzystny wpływ spinosadu na $P$. cespitum. Związek ten powodował nie tylko wyższą śmiertelność pająków w porównaniu z acetamiprydem i azadirachtyną, ale także osłabienie aktywności łowieckiej. Niewątpliwie najbardziej toksycznym insektycydem wobec badanych stadiów rozwojowych $T$. atrica był Fastac 100 EC. Pyretroidy są stosunkowo bezpieczne dla zwierząt stałocieplnych, charakteryzują się jednak małą wybiórczością wobec wielu innych gatunków stawonogów. Jak wykazały nasze wcześniejsze badania wrażliwość larw i nimf $T$. atrica na bifentrynę i zeta-cypermetrynę jest równie wysoka, jak na alfa-cypermetrynę (Szczepanik i wsp. 1997). Populacje dorosłych pająków są także silnie redukowane przez pyretroidy, co wykazano w laboratoryjnych badaniach nad wrażliwością $P$. cespitum na deltametrynę. Pod wpływem preparatu Decis 2,5 EC ginęło $80 \%$ dorosłych osobników tego gatunku.

\section{Wnioski / Conclusions}

1. Insektycyd Actara $25 \mathrm{WG}$ wykazywał najniższą toksyczność wobec larw i nimf 1 T. atrica.

2. Insektycydy Vertimec 018 EC i SpinTor 240 SC stosowane w niskich dawkach nie zagrażają wczesnym stadiom rozwojowym $T$. atrica; spinosad zastosowany w wyższych stężeniach powoduje wzrost śmiertelności $\operatorname{nimf}_{1}$.

3. Najwyższą toksyczność wobec badanych stadiów wykazywał Fastac 100 EC.

4. Najmniejsze różnice, w aktywności insektycydów związane z rodzajem zastosowanej metody aplikacji, obserwowano w przypadku tiametoksamu; pozostałe insektycydy wykazywały wyższą aktywność po zastosowaniu bezpośredniego oprysku pająków (metoda II) $\mathrm{W}$ porównaniu $\mathrm{z}$ kolonizacją na traktowanym podłożu (metoda I).

5. Actara $25 \mathrm{WG}$, Vertimec 018 EC oraz SpinTor $240 \mathrm{SC}$ stosowane racjonalnie $\mathrm{W}$ ramach integrowanych programów zwalczania szkodników nie stanowią większego zagrożenia dla wczesnych stadiów rozwojowych pająka T. atrica. Można przypuszczać także, że wrażliwość stadiów rozwojowych innych gatunków pająków na te insektycydy jest zbliżona.

\section{Literatura / References}

Abbott W.S. 1925. A method for computing the effectiveness of an insecticide. J. Econom. Entomol. 18: 265-267. 
Amalin D.M., Peńa J.E., Yu S.J., McSorley R. 2000. Selective toxicity of some pesticides to Hibana velox (Araneae: Anyphaenidae), a predator of citrus leafminer. Fla Entomol. 83(3): 254-262.

Jacuński J., Napiórkowska T., Tesznar L. 1999. Hodowla pająka Tegenaria atrica C.L. Koch. Przegl. Zool. 43 (1-2): 111-116.

Nyffeler M., Breene R.G., Dean D.A., Sterling W.L. 1990. Spiders as predators of arthropod eggs. J. Appl. Entomol. 109 (5): $490-501$.

Pekár S. 1998. Effect of selective insecticides on the beneficial spider community of a pear orchard in the Czech Republic. p. 337-342. In: Proc.17th European Colloquium of Arachnology (P.A. Selden, ed.). Edinburgh, 14-18 July 1997, 347 pp.

Prószyński J., Staręga W. 1971. Katalog fauny Polski, Pająki. PWN, Warszawa, 382 ss.

Řzác M., Pekár S., Stará J. 2010. The negative effect of some selective insecticides on the functional response of a potential biological control agent, the spider Philodromus cespitum. BioControl 55 (4): 503-510.

Szczepanik M., Jacuński L., Napiórkowska T., Tesznar L. 1997. Susceptibility of developmental stages of the spider, Tegenaria atrica C.L. Koch to pyrethorid insecticides. p. 233-236. In: "Insects Chemical, Physiological and Environmental Aspects" (D. Konopińska, ed.). Wyd. Uniwersytetu Wrocławskiego, Wrocław, 293 pp.

Topa E., Damszel M., Oleszczuk M., Hajdamowicz I. 2009. Fauna pająków naziemnych Araneae w sadach o zróżnicowanej intensywności ochrony. [Fauna of ground spiders Araneae in orchards with different intensity of protection]. Prog. Plant Prot./Post. Ochr. Roślin 49 (4): 1983-1986.

Wilczek G. 2008. Komórkowe strategie reakcji pająków na stres środowiskowy. Wyd. Uniwersytetu Śląskiego, Katowice, 117 ss. 